\title{
Histone H2B Type 1-D
}

National Cancer Institute

\section{Source}

National Cancer Institute. Histone H2B Type 1-D. NCI Thesaurus. Code C116688.

Histone H2B type 1-D (126 aa, $\sim 14 \mathrm{kDa}$ ) is encoded by the human $\mathrm{H} 2 \mathrm{BC} 5$ gene. This protein plays a role in the structure of nucleosomes. 